\title{
Maatilakytkentäisten yritysten kehityspolkuja
}

\author{
Margit Torkko \\ Seinäjoen ammattikorkeakoulu, Maa- ja metsätalouden yksikkö, Ilmajoentie 525, 60800 ILMAJOKI, \\ margit.torkko@seamk.fi
}

\section{Tiivistelmä}

Maatilojen monialaistuminen on yksi tapa vastata maatalouden tulojen vähenemiseen ja rakennemuutokseen. Yli kolmasosa Suomen maatiloista harjoittaa myös muuta yritystoimintaa. Monialaisten maatilojen harjoittaman yritystoiminnan jatkuminen ja liiketoiminnan kasvattaminen ehkäisevät maatilojen toiminnan lopettamista ja maaseudun autioitumista.

Maatilakytkentäisten yritysten kehittymisestä on olemassa vain vähän tutkimustietoa. Tämän tutkimuksen tavoitteena onkin kuvata maatilakytkentäisten yritysten kehittymistä sekä ymmärtää elinkaaren muodostumiseen johtaneita syitä. Tutkimuksessa vastataan seuraaviin tutkimuskysymyksiin: Millaisia kehityspolkuja maatilakytkentäisillä yrityksillä on tunnistettavissa? Mitkä tekijät ovat aiheuttaneet kyseisen kehityspolun muodostumisen? Miten maatila on kehittynyt yritystoiminnan rinnalla?

Tutkittava aihe on moni-ilmeinen, joten sitä lähestytään kvalitatiivisesti. Tutkimusmenetelmänä on case-tutkimus. Maatilakytkentäisiä yrityksiä on mukana kolmelta eri toimialalta: elintarvikkeiden jatkojalostus, matkailu ja koneurakointi. Yrityksiä on mukana kuusi kultakin kolmelta toimialalta eli yhteensä 18. Yrityksistä hankittiin tietoja ennalta lähetetyn taustatietolomakkeen, haastattelun ja muun saatavilla olleen materiaalin avulla.

Yrityksen kehittymistä voidaan mitata monella tavalla. Tässä liikevaihdon kehittymisen avulla tarkastellaan, noudattaako yritysten elinkaari jotain kirjallisuudesta löydettyä mallia. Kehittymistä tarkastellaan myös kuvaamalla, miten toiminta on muuttunut vuosien aikana. Lisäksi analysoidaan, miten yritykset ovat suunnanneet kasvua vuosien aikana.

Tutkimus antaa tietoa maatilakytkentäiset yrityksien kehittymisestä. Maatilojen muun yritystoiminnan kehityspolut seuraavat melko hyvin perinteistä elinkaarimallia (esim. Baliga ja Hunt 1988). Pitkään toimineiden maatilakytkentäisten yritysten kehityskaarissa ovat tunnistettavissa myös Kallion (2000) raportoimat mikroelinkaaret. Tutkimus vahvistaa näkökantaa, että muu yritystoiminta ei ole pelkkä siirtymävaihe maataloudesta yritystoimintaan, vaan niitä voidaan harjoittaa myös yhdessä.

Tutkimus osoittaa, että muun yritystoiminnan toimialalla on merkitystä maatilan kehittymiseen. Urakoitsijoista valtaosa on lisännyt myös maataloutta, kun taas matkailuyrittäjät ovat supistaneet tai pitäneet maatilan toiminnot samoina. Elintarvikeyrityksissä maatalous on kehittynyt vaihtelevasti. Tutkimuksen avulla on tunnistettu eri toimialoille tyypillisiä kehityspolkuja ja tekijöitä, jotka ovat vaikuttaneet muun yritystoiminnan kehittymiseen.

Asiasanat: maatilakytkentäinen yritys, monialainen maatila, elinkaari, kehittyminen 


\section{Johdanto}

Suomen maatalous on ollut muutoksessa EU:hun liittymisen jälkeen. Maatilojen monialaistuminen on yksi tapa vastata maatalouden tulojen vähenemiseen ja rakennemuutokseen. Suomessa maatilojen monialaistumiseen liittyvää tutkimusta on melko vähän, vaikka jo yli kolmasosa Suomen maatiloista saa tuloja muusta yritystoiminnasta. Rakennetutkimus 2003 (TIKE 2004) osoitti, että useat monialaiset tilat ovat lopettaneet muun yritystoiminnan vuosien 2000 ja 2003 välillä. Samanaikaisesti useat tilat ovat alkaneet harjoittaa muuta yritystoimintaa. Monialaisten maatilojen harjoittaman yritystoiminnan jatkuminen ja liiketoiminnan kasvattaminen ehkäisevät maatilojen toiminnan lopettamista ja maaseudun autioitumista.

Yrityksen kehittyminen ja kasvu ovat toisiinsa liittyviä termejä. Kasvulla tarkoitetaan yleensä liikevaihdon, taseen loppusumman, henkilömäärän tai jonkin muun mitattavissa olevan tekijän kasvua. Penrose (1959) löysi kasvussa myös muita tekijöitä. Hän tarkasteli yrityksen kasvua kehitysprosessina, jossa määrällisten mittareiden lisäksi käytettiin myös laadullisia tekijöitä.

Yrityksen kasvua ja kehittymistä mitataan usealla eri tavalla. Eniten käytettyjä mittareita ovat liikevaihto ja työllistävyys. Laukkasen (2000) mukaan kasvua tulee tarkastella myös laadullisesti. Hänen mukaan yrityksellä on kolme kasvusuuntaa: määrällinen, laadullinen ja näiden yhdistelmä. Määrällisessä kasvussa yrityksen henkilöstömäärä kasvaa, mutta johtamistapa, osaaminen ja johtamisjärjestelmät säilyvät. Laadullisessa kasvussa tapahtuu uusiutumista johtamisessa ja järjestelmissä. Lisäksi osaaminen lisääntyy. Laadullisen ja määrällisen kasvun tapahtuessa yhdessä yritys kasvaa ja viisastuu.

Yritysten kehittymistä voidaan tarkastella useasta eri tasosta: kansantalouden, alueen, toimialan ja yrityksen tasoista. Yrityksen kehittymistä kuvataan usein elinkaarimalleilla, jotka kuvaavat yrityksen kokoa ajan funktiona. Erilaisia elinkaarimalleja ovat esittäneet mm. Greiner 1972, Barnes ja Hershon 1976, Churchill ja Lewis 1983, Scott ja Bruce 1987, Baliga ja Hunt 1988, Bridge ym. 1998, Kallio 2000. Kuitenkaan ei ole löydetty yhtä kaikkien hyväksymää mallia. Elinkaarimalleille on esitetty myös kritiikkiä (ks. esim. Churchill ja Lewis 1983, Storey 1994, Koskinen 1996, Littunen 2001).

Rope (2003) on käsitellyt kasvun strategista suuntaamista Ansoffin (1965) matriisin avulla. Yritys voi kasvattaa toimintaansa suuntaamalla kasvua

- nykyiselle liiketoiminnalle. Kasvavilla markkinoilla kasvu saavutetaan säilyttämällä nykyinen markkinaosuus. Kasvua voidaan saavuttaa tuomalla markkinoille samaan tuoteryhmään kuuluvia uusia rinnakkaistuotteita tai uudistamalla vanhaa tuotetta.

- markkinalohkoa laventaen. Markkinoita voidaan laventaa segmenttiä laajentamalla eli laajennetaan aluetta maantieteellisesti tai toimialan sisällä. Radikaalimpi vaihtoehto on lanseerata tuote uusille markkinoille.

- tuotelohkoa laventaen. Kasvua haetaan tuomalla markkinoille parannettu tai täysin uusi tuote.

- tuote- ja markkinalohkoa laventaen.

Kasvustrategia aiheuttaa liiketoiminnan hallitsemiseen liittyviä riskejä. Riski kasvaa, kun laajennetaan tuote- tai markkinalohkoa. Pysyttäessä nykyisessä liiketoiminnassa ei oteta riskiä asiakas- tai tuoteosaamisessa. (Rope 2003.)

Maatilakytkentäisten yritysten kehittymisestä on olemassa vain niukalti tietoa. Tämän artikkelin tavoitteena on kuvata maatilakytkentäisten yritysten kehittymistä sekä ymmärtää elinkaaren muodostumiseen johtaneita syitä. Artikkelissa vastataan seuraaviin tutkimuskysymyksiin: Millaisia kehityspolkuja maatilakytkentäisillä yrityksillä on tunnistettavissa? Mitkä tekijät ovat aiheuttaneet kyseisen kehityspolun muodostumisen? Miten maatila on kehittynyt yritystoiminnan rinnalla? Tässä artikkelissa esitetyt tulokset pohjautuvat Torkon (2006) väitöskirjatutkimukseen.

\section{Aineisto ja menetelmät}

Tutkittava aihe on moni-ilmeinen, joten sitä lähestytään kvalitatiivisesti. Tutkimusmenetelmänä on case-tutkimus. Maatilakytkentäisiä yrityksiä valittiin kolmelta eri toimialalta: elintarvikkeiden jatkojalostus, matkailu ja koneurakointi. Yrityksiä oli mukana kuusi kultakin kolmelta toimialalta eli yhteensä 18. Yrityksistä hankittiin tietoja ennalta lähetetyn taustatietolomakkeen, haastattelun sekä muun saatavilla olleen materiaalin avulla, esimerkiksi kotisivut ja esitteet. Haastattelut tehtiin ajalla 
marraskuu 2004-helmikuu 2005. Seuraavaksi on kuvattu lyhyesti tutkimuksessa mukana olleita yrityksiä.

E1 on useita elintarviketuotteita valmistava osakeyhtiö, johon kuuluu maataloutta ja elintarvikkeiden jatkojalostusta. Yrityksen toiminta-alueita ovat tuoreena myytävien kasvisten viljely, kasvisten jatkojalostus, siipikarjanlihan tuotanto ja pienimuotoinen jalostus sekä perinteinen maanviljely.

E2 jatkojalostajaa ostoviljaa. Jatkojalostusta verotetaan elinkeinoverolain mukaan. Maatila on luomutila, jossa viljellään viljaa ja erästä juuresta.

E3 viljelee ja jalostaa erästä vihannesta. Toimintaa verotetaan maatilatalouden tuloverolain mukaan. Maatilan tuotantosuuntana on lihatuotanto. Muun yritystoiminnan tuotteita on viljeltävä vihannes, jota myydään sellaisenaan sekä jalostettuna.

E4 on osakeyhtiönä toimiva mylly. Maatilan toiminta on tällä hetkellä hyvin pienimuotoista, viljelyksessä on ainoastaan muutama hehtaari viljaa.

E5 on marjatila, joka valmistaa marjoista myös jatkojalosteita. Kaikkea toimintaa verotetaan maatilatalouden tuloverolain mukaan.

E6 kasvattaa eläimiä, joiden maidosta noin $90 \%$ menee sellaisenaan meijeriin ja noin $10 \%$ jalostetaan juustoksi. Toimintaa verotetaan maatilatalouden tuloverolain mukaan.

M1 tarjoaa pääasiassa majoitusta. Se toimii maatilatalouden tuloveron alaisena maatilan rinnalla. Maatilan tuotantosuuntana on kasvinviljely.

M2 tarjoaa monenlaisia matkailu- ja virkistyspalveluita. Se toimii maatilatalouden tuloverolain alaisena. Maatilan tuotantosuuntana on lihantuotanto; kaikki pelto on nurmella.

M3 tarjoaa kokous-, juhla- ja ohjelmapalveluita sekä majoitusta. Toimintaa verotetaan maatilatalouden tuloverolain mukaan. Matkailun lisäksi tilalla on myös muuta yritystoimintaa.

M4 tarjoaa juhla- ja kokouspalveluita sekä majoitusta. M4 on osakeyhtiö, jonka pääomistaja omistaa myös maatilan. Maatilan tuotantosuuntina ovat lihatuotanto ja kasvinviljely.

M5 tarjontaa ovat juhla- ja ateriapalvelut, kokouspalvelut, saunapalvelut ja majoitus sekä luontoretkien järjestäminen. Toimintaa verotetaan elinkeinoverolain mukaan. Maatilan päätuotantosuuntana on metsätalous ja lisäksi harjoitetaan kasvinviljelyä.

M6 tarjoaa juhla- ja ateriapalveluita, kokouspalveluita, saunapalveluita ja majoitusta. Matkailutoimintaa verotetaan elinkeinoverolain mukaan. Maatilalla on tuotantoeläimiä sekä kasvinviljelyä. Lisäksi tilalla on useita kotieläimiä.

U1 on urakointia harjoittava avoin yhtiö, jonka omistajilla on myös maatila. Maatilan toimintaan kuuluu kasvinviljelyä, metsätaloutta ja koneurakointia.

U2 on maatila, joka harjoittaa kasvinviljelyä ja maatalouskoneurakointia. Urakointia verotetaan maatilatalouden tuloverolain mukaan.

U3 on urakointia harjoittava erillinen osakeyhtiö, jonka palveluita ovat kaivinkoneurakointi ja metsäkoneurakointi. Maatilan lukuun harjoitetaan kasvinviljelyä ja maatalouskoneurakointia.

U4 on maatila, jonka toimintoja ovat kasvinviljely ja urakointi, jonka osuus tilan tuloista on yli puolet. Urakointipalveluja ovat kalkinlevitys, lietteenajo, lumityöt sekä muut sekalaiset työt. Urakointia verotetaan maatilatalouden tuloverolain mukaan.

U5 on maatila, jonka toimintoja ovat kasvinviljely, lihantuotanto sekä urakointi. Urakoinnin osuus maatilan tuloista on alle neljäsosa. Urakointipalveluja ovat energiaturpeennosto, kalkinlevitys, tienpito, maan kunnostustyöt, peltotyöt sekä satunnaiset muut työt. Urakointia verotetaan maatilatalouden tuloverolain mukaan.

U6 on kommandiittiyhtiö, jonka palveluita ovat maanrakennustyöt, suorakylvö, kasvinsuojeluruiskutus, puinnit, lumityöt ja kiinteistönhoito. Maatilan tuotantosuuntana on kasvinviljely.

Yrityksen kehittymistä voidaan mitata monella tavalla. Tässä liikevaihdon kehittymisen avulla tarkastellaan, noudattaako yritysten elinkaari jotain kirjallisuudesta löydettyä mallia. Kehittymistä tarkastellaan myös kuvaamalla, miten toiminta on muuttunut vuosien aikana. Lisäksi analysoidaan, miten yritykset ovat suunnanneet kasvua vuosien aikana.

\section{Tulokset ja tulosten tarkastelu}

\section{Elintarvikeyritysten liikevaihdon kehittyminen on esitetty kuvassa 1.}




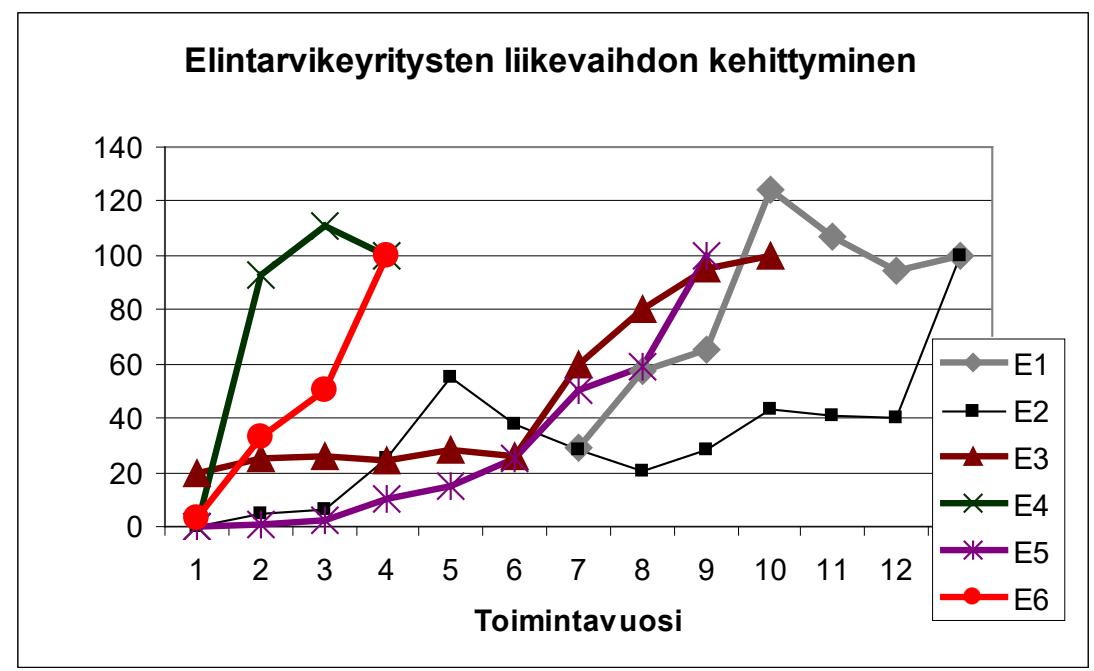

Kuva 1. Elintarvikeyritysten liikevaihdon kehittyminen, haastatteluhetkellä viimeisin toimintavuosi=100.

Elintarvikeyrityksillä kasvuun ovat vaikuttaneet mm. kokonaan uusien tuotteiden kehittäminen, tuoteperheiden laajennus, uusien markkinointikanavien löytäminen, uusille segmenteille laajentuminen, tunnettavuuden lisääntyminen sekä viljelyalan nosto. Sään vaikutus sadon määrään heijastuu tulokseen.

Elintarvikeyrityksillä on tunnistettavissa kehitysketju, jossa aluksi tuotetaan tilalla jotain jalostamatonta tuotetta. Myöhemmin aloitetaan pienimuotoinen jalosteiden valmistus. Myöhemmin lisätään tuotteita ja laajennetaan asiakaskuntaa. Tässä kehitysketjussa otetaan jalostuksen valmistuksen aloittamisen yhteydessä samanaikaisesti tuote- ja markkinariski. Markkinariskiä on pyritty madaltamaan sillä, että jo jalostamatonta tuotetta on myyty samoille asiakkaille. Yrittäjät pitivät jalostamattoman tuotteen myyntiä helpompana kuin jalostetun. Jalostettujen tuotteiden määrää on lisätty vuosien aikana. Elintarvikeyritykset ovat suunnannet kasvua voimakkaammin tuote- kuin markkinakentässä. Karkeasti voidaan todeta, että mitä suurempia riskejä oli otettu, sitä enemmän esiintyi ongelmia.

Matkailuyritysten liikevaihdon kehittyminen on kuvattu kuvassa 2.

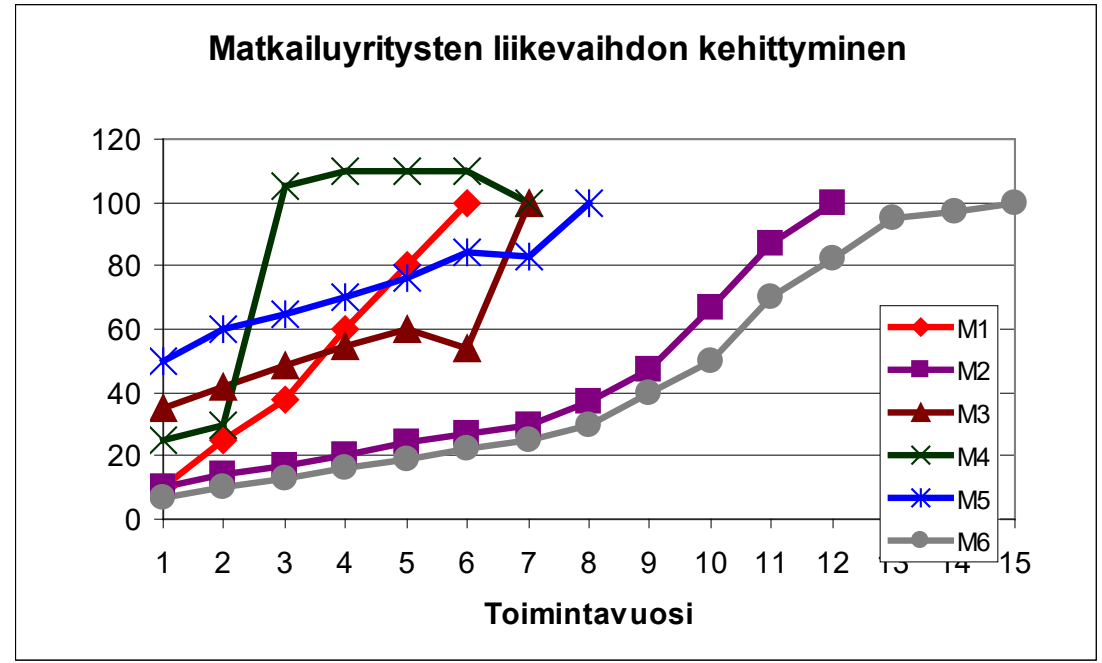

Kuva 2. Matkailuyritysten kehittyminen, haastatteluhetkellä viimeisin toimintavuosi $=100$.

Matkailuyritysten kehittymisen taustalla on laajentaminen, eli yrittäjät ovat rakentaneet lisää tilaa. Tunnettavuuden lisääntyminen on tehnyt laajentamisen mahdolliseksi. Yritykset ovat myös kehittäneet entisiä palveluja ja luoneet uusia. Kasvua on suunnattu pääasiassa laajentamalla asiakaskuntaa, mutta liikevaihtoa on pyritty kasvattamaan myös keräämällä toiminnan ympärille useita palveluita. Yksittäisiä syitä tunnettavuuden kasvuun on vaikea löytää. Yritykset ovat osallistuneet hankkeisiin ja yhteismarkkinointiin, mutta näiden osuutta tunnettavuuden lisääntymisessä on vaikea arvioida. 
Matkailuyrityksissä toiminta on yleensä alkanut pienimuotoisesti. Majoitusta ja tilaisuuksien järjestämisiä on aluksi tarjottu satunnaisesti. Kun palveluille on ollut kysyntää, on toiminta aloitettu vakavissaan. Pikkuhiljaa on lisätty kapasiteettia (rakennettu lisää, remontoitu vanhaa) ja alettu yhä tehokkaammin markkinoida palveluita. Vuosien aikana palveluvalikoimaa on laajennettu ja kehitetty. Samalla on tehostettu markkinointia uusien asiakkaiden saavuttamiseksi.

Matkailuyrityksissä palveluvalikoima ja asiakkaat ovat lisääntyneet vähitellen. Matkailuyrittäjien osalta näyttää, että toiminta on kasvanut, kun kasvun suuntaamisessa on otettu pienehköjä riskejä.

Matkailuyrityksissä kasvua on suunnattu hieman elintarvikeyrityksiä maltillisemmin. Koneurakointiyritysten liikevaihdon kehittyminen on esitetty kuvassa 3.

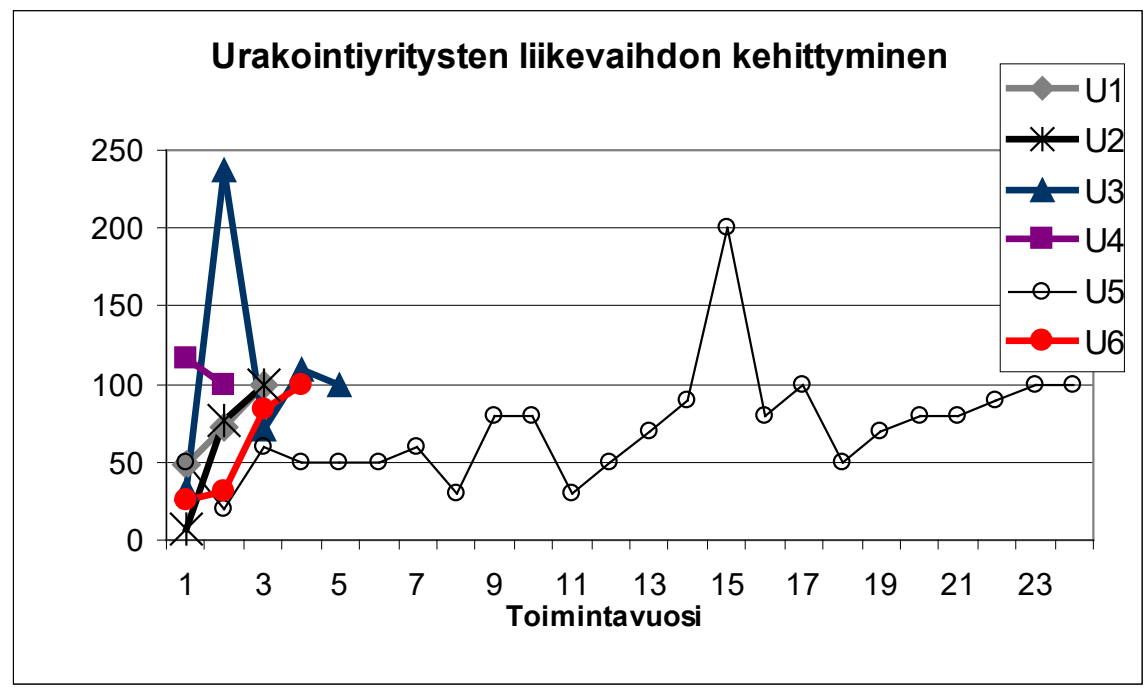

Kuva 3. Koneurakointiyritysten liikevaihdon kehittyminen, haastatteluhetkellä viimeisin toimintavuosi $=100$.

Urakoitsijoilla kasvu liittyy uusien palvelujen tarjoamiseen eli hankitaan jokin uusi kone, jolla aloitetaan urakointi. Kasvun taustalla on myös kysynnän lisääntyminen tunnettavuuden kasvaessa ja palveluvalikoiman laajentuessa. Liikevaihto kasvaa myös tehokkuuden myötä eli pienemmässä ajassa ehditään tehdä enemmän, mikä on tärkeää urakoinnissa, koska useat työt ajoittuvat lyhyisiin sesonkeihin. Sää vaikuttaa vuotuiseen tulokseen. Hyvän maineen saavuttaminen ja ylläpito on tärkeää.

Urakoitsijoilla on havaittavissa, että urakointitoimintaa on harjoitettu tilalla pitkän ajan. Yleensä jo vanhemmilla on ollut urakointia, joka maatilan sukupolvenvaihdoksessa siirtyy jatkajan huolehdittavaksi. Jatkaja ostaa uusia koneita, joilla urakointia saadaan kasvatettua. Mikäli palvelulle on kysyntää, kone vaihdetaan pian tehokkaammaksi.

Urakoitsijat ovat suunnanneet kasvua markkinakentässä muita ryhmiä maltillisemmin. Urakoitsijoilla kasvussa korostuu oikean palvelun tarjonta. Koneet ovat kalliita, joten oikean koneen ostaminen on ratkaisevaa. Kone on ostettava juuri oikeaan aikaan, jotta sillä tehtävälle työlle olisi kysyntää. Lainsäädäntö ja EU:n mukanaan tuomat säädökset vaikuttavat ajoitukseen. Myös asiakkaiden asenteilla on merkitystä. Perinteisesti maatiloilla on tehty työt itse, mutta tilakokojen kasvaessa asenteet ovat muuttuneet tai ovat muuttumassa siihen suuntaan, että yhä useampi tila ulkoistaa töitään. Esimerkiksi Niemelän ym. (2005) tulosten mukaan nautatiloilla tullaan käyttämään enenevässä määrin urakoitsijoita.

Tutkimuksessa mukana olleilla monialaisilla maatiloilla muun yritystoiminnan liikevaihdon kehitys on ollut nouseva. Muun yritystoiminnan kehityspolut seuraavat melko hyvin perinteistä elinkaarimallia (esim. Baliga ja Hunt 1988). Toisaalta pitkään toimineiden yritysten kehityskaarissa ovat tunnistettavissa Kallion (2000) raportoimat mikroelinkaaret.

Maatilan toiminnot ovat kehittyneet eri tavoin muun yritystoiminnan kehittymisen myötä. Muun yritystoiminnan toimialalla on vaikutusta maatilan kehittymiseen. Valtaosa urakoitsijoista on kasvattanut myös maatilan toimintaa. Elintarvikeyrityksistä yksi on kasvattanut maataloutta, kolme on supistanut ja kahdella elintarvikeyrityksellä maatila ja elintarvikkeiden jalostus ovat yhtä 
kokonaisuutta. Haastatelluista matkailutiloista yksikään ei ole lisännyt maatalouden roolia. Urakoitsijoista taas yksikään ei ole vähentänyt maatilan toimintaa.

Akselin (1995) mukaan maatilan monialaisuus on kokeiluvaihe, jonka jälkeen luovutaan maatilasta tai muusta yritystoiminnasta. Tätä tukee esimerkiksi Lassilan (2005) tutkimus, jossa mukana olleiden matkailutilojen harjoittaman maatalouden rooli oli pienentynyt ja sillä oli enää hyvin pieni merkitys lisäansioiden tuojana tai matkailuyrityksen liiketoimintoja tukevana toimintana. Matkailijoiden ja tuotantoeläinten keskimääräinen yhteishoivaamisaika oli 13 vuotta. (Lassila 2005.) Edellä esitetyistä tutkimuksista poiketen, tässä tutkimuksessa mukana olleista yrittäjistä valtaosa aikoo jatkaa sekä muuta yritystoimintaa että maataloutta. Maatalouden toimintoja voidaan yksinkertaistaa, mutta kukaan tutkimuksessa mukana olleista yrittäjistä ei ole luopumassa siitä kokonaan.

Tämän tutkimuksen perusteella voidaan todeta että maatila ja muu yritystoiminta toimivat yhdessä myös yritystoiminnan kokeilun jälkeen eli maatila ja muu yritystoiminta eivät ole pelkästään vaihtoehtoisia toisilleen. Samantapaisen tuloksen on raportoinut Rantamäki-Lahtinen (2004), joka tutki suomalaisten monialaisten tilojen tulevaisuuden suunnitelmia $(\mathrm{N}=365)$. Hänen aineistonsa mukaan $73 \%$ jatkaa sekä maataloutta että yritystoimintaa.

\section{Johtopäätökset}

Tutkimus antaa tietoa maatilakytkentäisten yritysten kehittymisestä. Muun yritystoiminnan kehityspolut seuraavat melko hyvin perinteistä elinkaarimallia (esim. Baliga ja Hunt 1988). Pitkään toimineiden maatilakytkentäisten yritysten kehityskaarissa ovat tunnistettavissa myös Kallion (2000) raportoimat mikroelinkaaret. Tutkimus vahvisti näkökantaa, että muu yritystoiminta ei ole pelkkä siirtymävaihe maataloudesta yritystoimintaan, vaan niitä voidaan harjoittaa myös yhdessä.

Tutkimuksen mukaan muun yritystoiminnan toimialalla on merkitystä maatilan kehittymiseen. Urakoitsijoista valtaosa on lisännyt myös maataloutta, kun taas matkailuyrittäjät ovat supistaneet tai pitäneet maatilan toiminnot samoina. Elintarvikeyrityksissä maatalous on kehittynyt vaihtelevasti.

Tutkimuksen avulla tunnistettiin eri toimialoille tyypillisiä kehityspolkuja ja tekijöitä, jotka ovat vaikuttaneet muun yritystoiminnan kehittymiseen. Elintarvikeyrityksillä toiminta yleensä lähtee liikkeelle itse tuotetun raaka-aineen jalostamisesta. Elintarvikeyritykset ovat suunnanneet kasvua voimakkaammin tuote- kuin markkinakentässä. Matkailuyrityksissä toiminta on yleensä alkanut pienimuotoisesti. Vuosien aikana palveluvalikoimaa on laajennettu ja parannettu. Samalla on tehostettu markkinointia uusien asiakkaiden saavuttamiseksi. Urakoitsijoilla kasvu liittyy uuden palvelun tarjoamiseen eli ostetaan uusi kone, jolla aloitetaan urakointi.

\section{Lähteet}

Akseli, A. 1995. Maataloustuottajasta maaseutuyrittäjäksi. Case-analyysi eteläpohjalaisten maanviljelijöiden yrittäjyyspäätöksistä. Raportteja ja artikkeleita 36. Helsingin yliopisto, Maaseudun tutkimus- ja koulutuskeskus, Seinäjoki.

Ansoff, H.I. 1965. Corporate Strategy: An Analytic Approach to Business Policy for Growth and expansion. McGraw-Hill, New York.

Baliga, B.R. \& Hunt, J.G. 1988. An organizational life cycle approach to leadership. Teoksessa: Hunt, J.G., Baliga, B.R., Dachler, H.P. \& Schriesheim, C.A. (toim.) Emerging Leadership Vistas. Lexington Books, Toronto, $129-149$.

Barnes, L.B. \& Hershon, S.A. 1976. Transferring power in the family business. Harvard Business Review 54 (4): $105-114$.

Bridge, S., O’Neill, K. \& Cromie, S. 1998. Understanding Enterprise, Entrepreneurship \& Small Business. Macmillan Press, Basingstoke.

Churchill, N.C. \& Lewis, V.L. 1983. The five stages of small business growth. Harvard Business Review, May-June: $30-50$.

Greiner, L. 1972. Evolution and revolution as organizations grow. Harvard Business Review, July-August: 3746.

Kallio, J. 2000. From unemployment to sustainable selfemployment? An analysis of the survival of new independent micro firms established by unemployed former start-up training programme participants in Scotland. Julkaisuja, sarja A-9. Turun kauppakorkeakoulu, Turku.

Koskinen, A. 1996. Pienyritysten kehityskaaret ja areenat. Acta Universitatis oeconomicae Helsingiensis A 116. Helsingin yliopisto, Helsinki.

Lassila, H. 2005. Matkailutilan sukupolvenvaihdos talonpoikaisten arvojen ohjaamana prosessina. Jyväskylä studies in business and economics 40. Jyväskylän yliopisto, Jyväskylä. 
Laukkanen, S. 2000. Uuden teknologiayrityksen kasvu. Tutkimusraportteja 1/00. Tampereen teknillinen korkeakoulu, Teollisuustalous, Tampere.

Littunen, H. 2001. Uusien yritysten menestyminen - Seurantatutkimuksen tulosten kansainvälinen vertailu. Tutkimuksia ja raportteja 21/2001. Kauppa- ja teollisuusministeriö, Helsinki.

Niemelä, T., Heikkilä, E. \& Meriläinen, T. 2005. Monialainen yritystoiminta Keski-Suomen maatiloilla. Julkaisuja N:o 148/2005. Jyväskylän yliopisto, Taloustieteiden tiedekunta, Jyväskylä.

Penrose, E. 1959. The Theory of the Growth of the Firm. Blackwell, Oxford.

Rantamäki-Lahtinen, L. 2004. Maatilojen monialaistuminen - Empiirinen analyysi monialaisuuteen vaikuttavista tekijöistä. Maa- ja elintarviketalous 50. MTT Taloustutkimus, Helsinki.

Rope, T. 2003. Johdon markkinointiratkaisut - Strateginen markkinointi. WSOY, Helsinki.

Scott, M. \& Bruce, R. 1987. Five stages of growth in small business. Long Range Planning 20 (3): 45-52.

Storey, D.J. 1994. Understanding the Small Business Sector. Routledge, London.

TIKE. 2004. Maatilojen muu yritystoiminta. Maatalouden rakennetutkimus 2003. Maa- ja metsätalousministeriön tietopalvelukeskus, Helsinki.

Torkko. M. 2006. Maatilakytkentäisten yritysten toimintamalleja: Laadullinen tutkimus resursseista, kehittymisestä ja ohjaustarpeista. Oulun yliopisto, Acta Universitatis Ouluensis, C 239, Oulu. 